УДК 618.11-008.64-02-092-06:618.177-08:618.17-089.888.11

DOI 10.11603/24116-4944.2019.1.10201

\author{
๑Г. В. Стрелко, Б. Айдин, В. В. Уланова, О. В. Малюта, Т. Г. Пісчана, Н. В. Короткевич, \\ М. Ю. Коробко \\ Медичний центр «Айвілед», Київ
}

\title{
ЗАСТОСУВАННЯ КАЛЬЦІЮ ІОНОФОРУ У ПАЦІЕНТОК ЗІ ЗНИЖЕНИМ РЕПРОДУКТИВНИМ ПРОГНОЗОМ У ПРОТОКОЛАХ ДРТ
}

\begin{abstract}
Мета дослідження - вивчення ефективності використання Са іонофору в протоколах EK3 - ICSI у пацієнток зі зниженим репродуктивним прогнозом.

Матеріали та методи. Проведено дослідження ефективності методики активації ооцитів у протоколах ЕКЗ - ICSI у пацієнток після як мінімум однієї невдалої спроби ДРТ. Застосовували ідентичні протоколи КСО. Результативність оцінювали, виходячи з ембріологічних (частота запліднення, дроблення ембріонів, відсоток бластуляції) і клінічних показників (частота настання вагітності).
\end{abstract}

Результати дослідження та їх обговорення. Застосування кальцію іонофору в момент проведення процедури ICSI дозволяє поліпшити відсоток запліднення ооцитів, відсоток дроблення, відсоток бластуляції. Це, у свою чергу, дозволило підвищити частоту настання вагітності в програмах EK3 - ICSI.

Висновок. Поліпшення ембріологічних показників дозволило істотно поліпшити результати щодо частоти настання вагітності в жінок старшого репродуктивного віку зі зниженим прогнозом по настанню вагітності.

Ключові слова: контрольована стимуляція яєчників; корифолітропін альфа; Ca ioнoфор; EK3; ICSI.

ПРИМЕНЕНИЕ КАЛЬЦИЯ ИОНОФОРА У ПАЦИЕНТОК СО СНИЖЕННЫМ РЕПРОДУКТИВНЫМ ПРОГНОЗОМ В ПРОТОКОЛАХ ВРТ

Цель исследования - изучение эффективности использования Са ионофора в протоколах ЭКО - ICSI у пациенток со сниженным репродуктивным прогнозом.

Материалы и методы. Проведено исследование эффрективности методики активации ооцитов в протоколах ЭКО - ICSI у пациенток после как минимум одной неудачной попытки ВРТ. Применялись идентичные протоколы КСО. Результативность оценивалась, исходя из эмбриологических (частота оплодотворения, дробления эмбрионов, процент бластуляции) и клинических показателей (частота наступления беременности).

Результаты исследования и их обсуждение. Применение кальция ионофора в момент проведения процедуры ICSI позволяет улучшить процент оплодотворения ооцитов, процент дробления, процент бластуляции. Это, в свою очередь, позволило повысить частоту наступления беременности в программах ЭКО - ICSI.

Вывод. Улучшение эмбриологических показателей позволило существенно улучшить результаты по частоте наступления беременности у женщин старшего репродуктивного возраста со сниженным прогнозом по наступлению беременности.

Ключевые слова: контролированная стимуляция яичников; корифоллитропин альфра; Са ионофор; ЭКО; ICSI.

THE USE OF CALCIUM IONOPHORE IN IVF - ICSI PROTOCOLS IN PATIENTS WITH A REDUCED REPRODUCTIVE PROGNOSIS

The aim of the study - to learn the effectiveness of the use of Ca ionophore in IVF - ICSI protocols in patients with a reduced reproductive prognosis.

Materials and Methods. A study was conducted of the effectiveness of the method of oocyte activation in ECO-ICSI protocols in patients after at least one unsuccessful attempt of ART. Identical CSR protocols were used. Effectiveness was estimated on the basis of embryological (frequency of fertilization, embryo cleavage, percentage of blastulation) and clinical indicators (frequency of pregnancy).

Results and Discussion. The use of calcium ionophore at the time of the ICSI procedure allows to improve the percentage of oocyte fertilization, the percentage of cleavage, the percentage of blastulation. This, in turn, has increased the pregnancy rate in the IVF-ICSI treatment.

Conclusion. Improvement of embryological parameters allowed to significantly improve the results of the frequency of pregnancy in women of older reproductive age with a reduced prognosis for the occurrence of pregnancy.

Key words: controlled ovarian stimulation; corinollitropin-alpha; Ca ionophore; IVF; ICSI.

ВСтУП. Проблема безплідного шлюбу сьогодні є актуальною, як ніколи. В середньому, 15-20\% подружніх пар відчувають труднощі з отриманням вагітності. Найбільш есрективним методом лікування безпліддя є екстракорпоральне запліднення (ЕКЗ). Успіх процедури залежить від безлічі фракторів, серед яких вік жінки, що визначає якість ооцитів, кількість яйцеклітин, якість сперматозоїдів. Велике значення мають також кваліфікація ембріологів і умови культивування ембріонів. Відповідно до стан- дартів роботи IVF лабораторії, відсоток запліднення ооцитів повинен становити не менше $70 \%$. У більшості випадків запліднення здійснюють шляхом введення одиночного сперматозоїда в цитоплазму ооцита (ICSI), при цьому відсоток запліднення повинен становити не менше 80-85 \% [1]. На жаль, все ще трапляється повна відсутність запліднення (в 1-3 \% всіх циклів) або його зниження (відсоток запліднених ооцитів становить менше 50 \%). В такому випадку істотно знижуються шанси на 
отримання ембріонів, які досягли стадії бластоцисти, що може призвести до відсутності вагітності і повторюватися протягом наступних спроб [2, 3]. Зниження запліднення або його відсутність може бути пов'язано з недостатністю активації ооцитів [3-5]. Причинами недостатності активації ооцита після запліднення можуть бути: порушення деконденсації хроматину головки сперматозоїда, передчасна конденсація хроматину сперматозоїдів, дефекти веретена або дефекти сперми і неправильна техніка ін'єкції сперматозоїда [6]. Крім того, невдача запліднення може бути викликана низькою життєздатністю, поганою рухливістю і морфологією (тератозооспермія, особливо глобозооспермія) сперматозоїдів [7-9].

Основним регуляторним механізмом активації ооцитів ссавців $є$ підвищення концентрації іонів кальцію в ооплазмі в результаті злиття мембрани головки сперматозоїда з оолемою. Така послідовність подій характерна для класичного ЕКЗ, тоді як при ICSI внутрішньоцитоплазматичне підвищення концентрації кальцію відбувається безпосередньо під час ін'єкції сперматозоїда в цитоплазму ооцита. Джерелом кальцію при цьому виступає культуральне середовище [10]. Даний механізм $€$ тригером процесу запліднення. Подальші коливання внутрішньоцитоцитоплазматичної концентрації кальцію $€$ результатом вивільнення з головки сперматозоїда фосфоліпази С дзета (PLCz) в ооплазму і відіграють ключову роль у подальшому розвитку ембріона $[11,12]$.

Слід зазначити, що вищеописаний механізм активації реалізується за умови остаточного дозрівання ооцитів, результатом якого $є$ зрілість ооплазми та її здатність генерувати коливання кальцію. Зрілість цитоплазми ооцита є ключовим фрактором для успішного запліднення [13]. Таким чином, при заплідненні, активація ооцита реалізується завдяки його здатності генерувати коливання рівнів кальцію у цитоплазмі у відповідь на $\mathrm{PLCz}$ сперматозоїда [14].

На даний момент існує кілька описаних у літературі підходів для штучної стимуляції підвищення концентрації кальцію в ооплазмі, серед яких механічні, електричні та хімічні стимули [15-17]. В даному дослідженні, як хімічну стимуляцію, ми використовували іонофор кальцію - кальциміцин (А23187), механізм дії якого полягає в здатності вбудовуватися в мембрану ооцита, дозволяючи іонам кальцію проникати в ооплазму завдяки градієнту концентрації.

Таким чином, з огляду на роль Са в процесах запліднення і розвитку ембріона, основною метою даного дослідження був порівняльний аналіз результативності програм ЕКЗ у пацієнтів з одним і більше невдалим протоколом в анамнезі порівняно з застосуванням іонофору. Аналізували такі показники, як кількість ооцитів, ступінь їх зрілості, відсоток запліднення і дроблення, частка ембріонів з наявністю фрагментації, відсоток виходу бластоцист і частота настання вагітності.

МАТЕРІАЛИ ТА МЕТОДИ. Для вирішення поставленої мети було проспективно обстежено 45 жінок із безпліддям. Показаннями до включення жінок у дослідження були невдалі протоколи в анамнезі. 3 дослідження були виключені жінки з аномальним каріотипом, гострими запальними захворюваннями будь-якої локалізації на початок лікувальної програми ДРТ, вродженими вадами розвитку або набутими десормаціями порожнини матки, при яких неможлива імплантація ембріона і виношування вагітності, доброякісними пухлинами матки, що деформують порожнину матки і (або) вимагають оперативного лікування, злоякісними новоутвореннями будь-якої локалізації.

Клінічне обстеження пацієнток проводили за спеціально розробленою анкетою, яка включала насамперед детальний збір анамнестичних даних, стан менструальної і репродуктивної функції, гінекологічний і соматичний статус. Прогнозування відповіді яєчників на стимуляцію проводили шляхом визначення оваріального резерву, а саме за допомогою оцінки сонографрічних і ендокринних показників на 2-й або 3-й день спонтанного менструального циклу до початку контрольованої стимуляції яєчників. Саме сироватковий рівень АМГ показав кращу кореляцію $з$ кількістю ооцитів порівняно з іншими предикторами оваріальної відповіді. Так, визначення рівня антимюллерового гормону проводилося методом твердофразного імуноферментного аналізу (ELISA) з тестсистемами Beckman Coulter (США).

Ультразвукове сканування проводили на апаратах PHILIPSATL-HDI 4000, PHILIPS HD 11-XE. В процесі стимуляції суперовуляції проводили ультразвуковий моніторинг для динамічної оцінки зростання і дозрівання фолікулів у яєчниках (фуннціонально зрілий фолікул розмірами 1820 мм), приросту ендометрія. Ультразвукову діагностику вагітності виконували на 21 день після перенесення ембріона з контролем серцебиття в терміні 6-7 тижнів.

Для контрольованої стимуляції яєчників використовували новий гормональний препарат для лікування безпліддя, що відноситься до нового класу рекомбінантних гонадотропінів пролонгованої дії, - корифолітропін альфра. Особливістю цієї молекули є вдвічі більший період напіввиведення порівняно зі стандартним рекомбінантним ФСГ. Ця властивість дозволяє ініціювати і підтримувати мультифолікулярний ріст протягом 7 днів після одноразової підшкірної ін'єкції. Згідно з даними літератури, корисролітропін альфа в дозі 150 мкг ініціює в середньому трохи більш сильну відповідь яєчників порівняно $з$ добовою щоденною дозою ФСГ $200 \mathrm{MO}$, що дозволило використовувати препарат з метою контрольованої стимуляції яєчників у поганих відповідачів у поєднанні з додатковими дозами ФСГ і антагоністами гонадотропін-рилізинг-гормону для спрощення дизайну схеми стимуляції, мінімізації кількості ін'єкцій і укорочення тривалості стимуляції (табл. 1).

Для підготовки клітин і проведення процедури ICSI були використані середовища виробництва Sage, Global, Origio та Irvine Scientiffic. Клітини отримували шляхом трансвагінальної аспірації фролікулів. Збір ооцитів проводили в стерильних умовах під ламінарною шафою при дотриманні відповідного температурного режиму $\left(37^{\circ} \mathrm{C}\right)$. Ооцит-кумулюсні комплекси поміщали в середовище

Таблиця 1. Схема призначення корифолітропіну альфа

\begin{tabular}{|c|c|c|}
\hline Елонва, мкг & Додатковий ФСГ, МО & \multicolumn{1}{|c|}{ Антагоніст ГнРГ } \\
\hline 150 & $200-300$ & Стандартно 3 6-го дня стимуляції або за наявності фролікула >14 мм \\
\hline \hline
\end{tabular}


для збору ооцитів (Global Collect). Після відмивання ооцит-кумулюсні комплекси витримували 1-2 години в культиваційних середовищах при концентрації $\mathrm{CO}_{2}$ в атмоссрері $6 \%$ і температурі $37^{\circ} \mathrm{C}$ до моменту денудації.

Для очищення ооцитів від клітин кумулюса використовували гіалуронідазу (Irvine Scientiffic). Для запобігання пошкодженню яйцеклітини використовували піпетки 3 відповідним розміром просвіту, уникаючи занадто енергійного піпетування. Після денудації ооцити ретельно промивали, щоб видалити залишки гіалуронідази. Стадію зрілості ооцитів протоколювали. Денудація проводилася через певний час після введення тригера фрінального дозрівання (35-36 годин). 3 огляду на те, що денудовані ооцити більш чутливі до змін pH, процедура ICSI проводилася відразу після денудації. Як середовище для проведення процедури ICSI використовували середовище 3 додаванням HEPES (Sage, «Quinn's Advantage Medium»). Запліднюють тільки ооцити на стадії MII. Морфологію ооцитів оцінювали додатково. Гігантські ооцити або ооцити 3 морфологічними аномаліями полярного тіла не запліднюються. Для запліднення використовували морсологічно нормальні, рухливі сперматозоїди. Ін'єкцію проводили далеко від полярного тіла ооцита.

Чашки з краплями середовища, що містить іонофрор кальцію, готували за 3-4 години до початку процедури ICSI і містили в інкубатор для врівноваження при концентрації $\mathrm{CO}_{2}$ в атмоссрері 6 \%. Безпосередньо після завершення процедури ICSI клітини витримували в середовищі з додаванням іонофору кальцію при концентрації $\mathrm{CO}_{2}$ в атмоссрері $6 \%$ і температурі $37{ }^{\circ} \mathrm{C}$ (Gynemed, «GM508 Cult Active») протягом 15 хвилин. По закінченні інкубування клітини ретельно промивали в краплях культиваційного середовища (Origio, «One step») і переносили в краплі свіжого культиваційного середовища того ж виробника для подальшого культивування при концентрації $\mathrm{CO}_{2}$ в атмоссрері $6 \%$, кисню $5 \%$ і температурі $37^{\circ} \mathrm{C}$. Через 16-18 годин проводили оцінку запліднення, виходячи 3 наявності пронуклеусів.

РЕЗУЛЬТАТИ ДОСЛІДЖЕННЯ ТА ЇХ ОБГОВОРЕНня. Отже, середній вік пацієнток досліджуваної групи склав $(38,6 \pm 3,9)$ року. За індексом маси тіла, середній його показник у досліджуваних жінок склав $(22,02 \pm$ $2,9)$ кг/M², тобто переважна більшість жінок мала нормальні показники маси тіла. 3 огляду на те, що порівняння проводилося в тих же пацієнток через кілька місяців, показники середнього віку і ІМТ не відрізнялися в групах.

Вивчення репродуктивної функції встановило, що первинне безпліддя спостерігалося у 32 (71,1 \%) і вторинне $-13(28,9 \%) .3$ огляду на те, що повторне проведення лікування проводилося в тих же пацієнток, структура безпліддя в групах була ідентичною: в $60 \%$ випадків $(n=27)$ було виявлено чоловічий срактор безпліддя, в 57,8 \% - трубноперитонеальний ( $n=26)$, в $20 \%$ - знижений оваріальний резерв $(n=9)$, в 13,3 \% - безпліддя неясного генезу $(n=6)$.

Ми проаналізували результат стимуляції, кількість отриманих ооцитів, дроблення ембріонів, а також показники вагітності та імплантації.

У таблиці 2 представлені дані результатів стимуляції в групах, і вони виявились ідентичними, адже протоколи КСО проводилися в одних і тих же пацієнток за стандартною схемою, описаною вище.

У таблиці 3 представлені дані щодо кількості отриманих ооцитів, ступеня їх зрілості, відсотка запліднення і бластуляції після використання Са іонофору і без його застосування. Привертає увагу висока частота настання вагітності в досліджуваній групі.

Таблиця 2. Порівняльна характеристика протоколів стимуляції

\begin{tabular}{|l|c|c|c||}
\hline \multicolumn{1}{|c|}{ Показники } & $\begin{array}{c}\text { Група 1 } \\
\mathrm{N}=45\end{array}$ & $\begin{array}{c}\text { Група 2 } \\
\text { Са iонорор } \\
\mathrm{N}=45\end{array}$ & $\mathrm{P}$ \\
\hline Середній вік (років) & $38,6 \pm 3,9$ & $38,6 \pm 3,9$ & $\mathrm{P}>0,05$ \\
\hline Середній індекс маси тіла (кг/м²) & $22,02 \pm 2,9$ & $22,02 \pm 2,9$ & $\mathrm{P}>0,05$ \\
\hline Середній АМГ & $1,34 \pm 0,75$ & $1,34 \pm 0,75$ & $\mathrm{P}>0,05$ \\
\hline Середня тривалість безпліддя & $5,77 \pm 4,21$ & $5,77 \pm 4,21$ & $\mathrm{P}>0,05$ \\
\hline Середня тривалість стимуляції & $9,5 \pm 0,04$ & $9,7 \pm 0,05$ & $\mathrm{P}>0,05$ \\
\hline $\begin{array}{l}\text { Середня додаткова доза ФСГ після 7 } \\
\text { днів стимуляції (МО) }\end{array}$ & $1242,86 \pm 119,35$ & $1267,93 \pm 125,74$ & $\mathrm{P}>0,05$ \\
\hline
\end{tabular}

Таблиця 3. Ефективність застосування Са іонофору в протоколах ДРТ

\begin{tabular}{|l|c|c|c||}
\hline \multicolumn{1}{|c|}{ Показник } & Без застосування Са іонорору & Застосування Са іонорору & $\mathrm{P}$ \\
\hline Кількість ооцитів & $11,0 \pm 3,8$ & $10,7 \pm 4,5$ & $\mathrm{P}>0,05$ \\
\hline M II & $8,5 \pm 2,6$ & $8,3 \pm 3,1$ & $\mathrm{P}>0,05$ \\
\hline Запліднення 2pn, \% & $6,9 \pm 1,3$ & $7,9 \pm 1,7$ & $\mathrm{P}>0,05$ \\
& $(81,3 \%)$ & $(96,54 \%)$ & $\mathrm{P}>0,05$ \\
\hline Дроблення, \% & $6,6 \pm 1,9$ & $7,7 \pm 2,1$ & \\
\hline Кількість бластоцист, \% & $(77,7 \%)$ & $5,9 \pm 0,1$ & $(71,3 \%)$ \\
& $4,2 \pm 0,2$ & $1,4 \pm 0,7$ & $\mathrm{P}<0,05$ \\
\hline Кількість ембріонів на трансрер & $(49,2 \%)$ & 26 & $\mathrm{P}>0,05$ \\
\hline Частота настання вагітності, \% & $1,6 \pm 0,5$ & $57,8 \%$ & $\mathrm{P}<0,05$ \\
& 0 & & \\
\hline \hline
\end{tabular}


Результати дослідження дозволяють зробити висновок про позитивний вплив використання кальцію іонофору в протоколах ДРТ. Важливу роль у результативності лікування відіграє якість ооцита і його здатність до активації в момент запліднення. 3 огляду на високий середній вік пацієнток, попередні невдалі протоколи ДРТ, передбачуваний прогноз настання вагітності у даної групи пацієнток був досить низьким. Істотне поліпшення ембріологічних показників, а саме частоти запліднення, дроблення, отримання ембріонів хорошої якості, а також частоти настання вагітності, дозволяє широко рекомендувати дану методику роботи з ооцитами.

ВисновкИ. 1. Застосування кальцію іонофору в момент проведення процедури ICSI дозволяє поліпшити відсоток запліднення ооцитів, відсоток дроблення, відсоток бластуляції.

2. Застосування кальцію іонофрору дозволило отримати хороші результати у жінок старшого репродуктивного віку зі зниженим прогнозом по настанню вагітності.

3. Застосування даної методики може бути рекомендовано в повторних спробах ЕКЗ і у пацієнток зі зниженою якістю ооцитів.

4. Дана методика може бути рекомендована в якості рутинного методу роботи з ооцитами в програмах ДРТ.

ПЕРСПЕКТИВИ ПОДАЛЬШИХ ДОСЛІДЖЕНЬ. 3 метою визначення груп пацієнтів, де можливо очікувати особливі переваги від застосування даної методики, необхідне проведення широкомасштабних багатоцентрових рандомізованих досліджень.

\section{СПИСОК ЛІТЕРАТУРИ}

1. ICSI: where we have been and where we are going / G. D. Palermo, Q. V. Neri, T. Takeuchi, Z. Rosenwaks // Semin. Reprod. Med. - 2009. - Vol. 27. - P. 191-201.

2. Aetiology of failed and abnormal fertilization after intracytoplasmic sperm injection / S. P. Flaherty, D. Payne, N. J. Swann, C. D. Mattews // Hum. Reprod. - 1995. - Vol. 10. P. 2623-2629.

3. Flaherty S. P. Fertilization failures and abnormal fertilization after intracytoplasmic sperm injection / S. P. Flaherty, D. Payne, C. D. Matthews // Hum. Reprod. - 1998. - Vol. 13 (Suppl. 1). - P. 155-164.

4. Analysis of 76 total fertilization failure cycles out of 2732 intracytoplasmic sperm injection cycles / H. Tournaye, J. Smitz, M. Camus // Hum. Reprod. - 1995. - Vol. 10. - P. 2630-2636.

5. Cytoskeletal organization defects and abortive activation in human oocytes after IVF and ICSI failure / V. Y. Rawe, S. B. Olmedo, F. N. Nodar [et al.] // Mol. Hum. Reprod. - 2000. - Vol. 6. - P. 510-516.

6. Swain J. E. ART failure: oocyte contributions to unsuccessful Fertilization / J. E. Swain, T. B. Pool // Hum. Reprod. Update. - 2008. - Vol. 14. - P. 431-446.

7. Yanagida K. Complete fertilization failure in ICSI / K. Yanagida // Hum. Cell. - 2004. - Vol. 17. - P. 187-193.

8. Successful fertilization and pregnancy following ICSI and electrical oocyte activation / K. Yanagida, H. Katayose, H. Yazawa // Hum. Reprod. - 1999. - Vol. 14. - P. 1307-1311.

9. Yanagida K. Successful pregnancy after ICSI with strontium oocyte activation in low rates of fertilization K. Yanagida, K. Morozumi, H. Katayose // Reprod. Biomed. Online. - 2006. - Vol. 13. - P. 801-806.

\section{REFERENCES}

1. Palermo, G.D., Neri, Q.V., Takeuchi, T., \& Rosenwaks, Z. (2009). ICSI: where we have been and where we are going Semin. Reprod. Med., 27, 191-201.

2. Flaherty, S.P., Payne, D., Swann, N.J., \& Mattews, C.D. (1995). Aetiology of failed and abnormal fertilization after intracytoplasmic sperm injection. Hum. Reprod., 10, 2623-2629.

3. Flaherty, S.P., Payne, D., \& Matthews, C.D. (1998). Fertilization failures and abnormal fertilization after intracytoplasmic sperm injection. Hum. Reprod., 13 (Suppl. 1), 155-164.
10. Tesarik J. The activity (calcium oscillator?)responsible for human oocyte activation after injection with round spermatids is associated with spermatid nuclei / J. Tesarik, C. Mendoza, E. Greco // Fertil. Steril. - 2000. - Vol. 74. - P. 1245-1247.

11. Flipping the switch: how a sperm activates the egg at fertilization / J. Parrington, L. C. Davis, A. Galione, G. Wessel // Dev. Dyn. - 2007. - Vol. 236. - P. 2027-2038.

12. Oocyte activation, phospholipase $C$ zeta and human infertility / J. Kashir, B. Heindryckx, C. Jones [et al.] // Hum. Reprod. Update. - 2010. - Vol. 16. - P. 690-703.

13. AjdukA. Cytoplasmic maturation of mammalian oocytes: development of a mechanism responsible for sperm-induced Ca2+ oscillations / A. Ajduk, A. Malagocki, M. Maleszewski // Reprod. Biol. - 2008. - Vol. 8. - P. 3-22.

14. Tesarik J. In vitro fertilization by intracytoplasmic sperm Injection / J. Tesarik, C. Mendoza // Bioessays. - 1999. Vol. 21. - P. 791-801.

15. Use of a modified intracytoplasmic sperm injection technique to overcome sperm-borne and oocyte-borne oocyte activation failures / J. Tesarik, L. Rienzi, F. Ubaldi [et al.] // Fertil. Steril. - 2002. - Vol. 78. - P. 619-624.

16. Borges E. Jr. Artificial oocyte activation using calcium ionophore in ICSI cycles with spermatozoa from different sources / E. Jr. Borges, D. P. de Almeida Ferreira Braga, T. C. de Sousa Bonetti // Reprod. Biomed. Online - 2009. - Vol. 18. - P. 45-52.

17. Assisted oocyte activation is not beneficial for all patients with a suspected oocyte-related activation / F. Vanden Meerschaut, D. Nikiforaki, S. De Gheselle [et al.] // Deficiency Human Reproduction. - 2012. - Vol. 27, No.7. P. 1977-1984. 
6. Swain, J.E., \& Pool, T.B. (2008). ART failure: oocyte contributions to unsuccessful fertilization. Hum. Reprod. Update, 14, 431-446.

7. Yanagida, K. (2004). Complete fertilization failure in ICSI. Hum. Cell, 17, 187-193.

8. Yanagida, K., Katayose, H., Yazawa, H., Kimura, Y., Sato, A. Yanagimachi, H., \& Yanagimachi, R. (1999). Successful fertilization and pregnancy following ICSI and electrical oocyte activation. Hum. Reprod., 14, 1307-1311.

9. Yanagida, K., Morozumi, K., Katayose, H., Hayashi, S., \& Sato, A. (2006). Successful pregnancy after ICSI with strontium oocyte activation in low rates of fertilization. Reprod. Biomed. Online, 13, 801-806.

10. Tesarik, J., Mendoza, C., \& Greco, E. (2000). The activity (calcium oscillator?) responsible for human oocyte activation after injection with round spermatids is associated with spermatid nuclei. Fertil. Steril., 74, 1245-1247.

11. Parrington, J., Davis, L.C., Galione, A., \& Wessel, G. (2007). Flipping the switch: how a sperm activates the egg at fertilization. Dev. Dyn., 236, 2027-2038.

12. Kashir, J., Heindryckx, B., Jones, C., De Sutter, P., Parrington, J., \& Coward, K. (2010). Oocyte activation, phospholipase C zeta and human infertility. Hum. Reprod. Update, 16, 690-703.

13. Ajduk, A., Malagocki, A., \& Maleszewski, M. (2008). Cytoplasmic maturation of mammalian oocytes: development of a mechanism responsible for sperm-induced $\mathrm{Ca} 2+$ oscillations. Reprod. Biol., 8, 3-22.

14. Tesarik, J., \& Mendoza, C. (1999). In vitro fertilization by intracytoplasmic sperm injection. Bioessays, 21, 791-801.

15. Tesarik, J., Rienzi, L., Ubaldi, F., Mendoza, C., \& Greco, E. (2002). Use of a modified intracytoplasmic sperm injection technique to overcome sperm-borne and oocyte-borne oocyte activation failures. Fertil. Steril., 78, 619-624.

16. Borges, E.Jr., de Almeida Ferreira Braga, D.P., de Sousa Bonetti, T.C., Iaconelli, A.Jr., \& Franco, J.G.Jr. (2009). Artificial oocyte activation using calcium ionophore in ICSI cycles with spermatozoa from different sources. Reprod. Biomed. Online, $18,45-52$

17. Vanden Meerschaut, F., Nikiforaki, D., De Gheselle, S., Dullaerts, V., Van den Abbeel, E., Gerris, J., ... \& De Sutter, P. (2012). Assisted oocyte activation is not beneficial for all patients with a suspected oocyte-related activation. Deficiency Human Reproduction, 27, 7, 1977-1984. 